\title{
Allostaffia, a new genus name for Staffia Heinrich, 1999 (Allotheria, Haramiyida) preoccupied by Staffia Schubert, 1911 (Protista, Foraminifera)
}

\author{
Wolf-Dieter Heinrich ${ }^{1}$
}

\begin{abstract}
The genus name Staffia Heinrich, 1999 published for a Jurassic allotherian mammal from Tendaguru, Tanzania, is preoccupied by Staffia Schubert, 1911 (Protista, Foraminifera). A replacement name, Allostaffia, is proposed here.
\end{abstract}

Key words: Taxonomy, nomenclature, Allotheria, Haramiyida, Staffia, Allostaffia, Upper Jurassic, Tendaguru, Gondwana

\section{Zusammenfassung}

Der Gattungsname Staffia Heinrich, 1999, der für einen Haramiyiden (Mammalia, Allotheria) aus dem Oberjura von Tendaguru, Tansania (Ostafrika) vergeben wurde, ist durch Staffia Schubert, 1911 (Protista, Foraminifera) präokkupiert. Er wird daher durch den neuen Namen Allostaffia ersetzt.

Schlüsselwörter: Taxonomie, Nomenklatur, Allotheria, Haramiyida, Staffia, Allostaffia, Oberjura, Tendaguru, Gondwana

The name Staffia aenigmatica was proposed by Heinrich (1999) for the first haramiyid to be discovered in Gondwana. The taxon was named on the basis of an isolated cheek tooth, identified tentatively as a right lower posterior premolar (Heinrich 1999), recovered from the Upper Jurassic (Kimmeridgian-Tithonian) of Tendaguru in Tanzania, East Africa. Additional dental material, collected later from the same site was also assigned to this taxon (Heinrich 2001). This genus name was created to honour $\mathrm{H}$. von Staff (1883-1915), who ran excavations of the German Tendaguru expedition in 1911.

Recently, Dr. Ch. F. Kammerer (in litt.) found that Staffia Heinrich, 1999 is preoccupied by the foraminiferan Staffia Schubert, 1911 and should be replaced according to the rules of the ICZN (1999). Therefore, I propose the substitute name Allostaffia. The replacement name is derived from the name of the German geologist and paleontologist $H$. von Staff and the Greek word for "different" or "other" (allós) refering to the systematic position of this genus within the allotherian mammals.

\section{Acknowledgements}

I thank Dr. Christian F. Kammerer (Chicago) for bringing the synonymy to my attention and Dr. David Unwin (Berlin) and Dr. Robert Asher (Berlin) for assistance.

\section{References}

Heinrich, W.-D. 1999. First haramiyid (Mammalia, Allotheria) from the Mesozoic of Gondwana. - Mitteilungen aus dem Museum für Naturkunde in Berlin, Geowissenschaftliche Reihe 2: 159-170.

- 2001. New records of Staffia aenigmatica (Mammalia, Allotheria, Haramiyida) from the Upper Jurassic of Tendaguru in southeastern Tanzania, East Africa. - Mitteilungen aus dem Museum für Naturkunde in Berlin, Geowissenschaftliche Reihe 4: 239-255.

ICZN 1999. International Code of Zoological Nomenclature, Fourth Edition. 306 pp, International Trust for Zoological Nomenclature and The Natural History Museum, London.

Schubert, R. 1911. Die fossilen Foraminiferen des Bismarckarchipels und einiger angrenzender Inseln. - Abhandlungen der K. K. Geologischen Reichsanstalt Wien 20 (4): $1-130$.

\footnotetext{
1 Museum für Naturkunde, Institut für Paläontologie, Invalidenstr. 43, D-10115 Berlin, Germany. Received May 2004, accepted June 2004
} 